\title{
Adult systemic oxalosis presenting as acute renal failure
}

\author{
H. OLI \\ M.B., Ch.B.(Edin.), M.R.C.P.(U.K.), \\ A. M. DAVISON
B.Sc., M.B., Ch.B.(Edin.), M.R.C.P.(U.K.) \\ Department of Renal Medicine, St James's University Hospital, Leeds
}

\begin{abstract}
Summary
A case is reported of an adult who presented with acute renal failure and who was subsequently found to have widespread deposition of oxalate in many tissues.
\end{abstract}

\section{Introduction}

Systemic oxalosis is an uncommon condition in which there is a disorder of oxalic acid metabolism producing an accumulation of oxalic acid with subsequent deposition of oxalates in tissues, commonly leading to the development of nephrocalcinosis with an early death from renal failure. The condition is inherited as a recessive disorder and recent studies indicate a failure to convert glyoxylic acid to carbon dioxide and/or a defective transamination of glyoxylate to glycine (Dean, Griffin and Watts, 1966; Hockaday et al., 1964; Zarembski, Hodgkinson and Parsons, 1966). An adult is now reported who presented with acute renal failure and who was subsequently found to have widespread deposition of oxalates in many tissues.

\section{Case report}

A 28-year-old lorry driver was admitted to hospital with a 3-week history of lethargy, nausea and vomiting. Examination showed him to be anaemic, normotensive and in sinus rhythm. On admission his blood urea was $75.7 \mathrm{mmol} / \mathrm{l}$ with a serum potassium of $5.8 \mathrm{mmol} / 1$ and a bicarbonate of $15 \mathrm{mmol} / \mathrm{l}$. His haemoglobin was $88 \mathrm{~g} / 1$.

An abdominal X-ray revealed bilateral renal calcification and a diagnosis of chronic renal failure secondary to nephrocalcinosis was made. There was no significant past history and detailed systematic enquiry was unrevealing.

The morning after admission he collapsed, became shocked and was found to have an irregular pulse. ECG showed A-V dissociation and transvenous cardiac pacing was performed. In view of his uraemic symptoms, peritoneal dialysis was undertaken for $24 \mathrm{hr}$. Following this, he was transferred to the

Reprint requests to Dr A. M. Davison.
Regional Renal Unit for further management and investigation.

On transfer he was anuric, had evidence of con- 3 . gestive cardiac failure and his blood pressure was of $140 / 100 \mathrm{mmHg}$. A transvenous pacemaker was $\delta$ pacing at $80 / \mathrm{min}$. There were no other abnormalities on physical examination. Peritoneal dialysis had $\stackrel{+}{+}$ satisfactorily reduced his blood urea to $53.5 \mathrm{mmol} / \mathrm{l}$ 음 but his serum creatinine was grossly elevated at $2730 \mathrm{mmol} / 1$. Serum calcium was $1.84 \mathrm{mmol} / \mathrm{l}$ with a plasma uric acid of $0.77 \mathrm{mmol} / \mathrm{l}$.

Retrograde pyelography showed extensive nephrocalcinosis with large opacifications within the calyces of the right kidney. Large clubbed calyces $\vec{\theta}$ were demonstrated in the lower pole of the rigli 6 kidney but no contrast reached the upper pose calyces indicating obstruction by stones. No abnormality was seen in the ureters or bladder. On the left side calcification appeared within the renal parenchyma but there was no calyceal dilatation. A $\stackrel{\mathbb{Q}}{\propto}$ skeletal survey revealed widespread evidence of renal $\overrightarrow{\vec{P}}$ osteodystrophy.

A further peritoneal dialysis was performed for $24 \mathrm{hr}$ and as his A-V dissociation continued a permanent pacemaker was inserted. The right kidney was explored surgically and a large number of stones 3 . removed. Following the operation he produced $\dot{\sigma}$ approximately $50 \mathrm{ml}$ of urine $/ 24 \mathrm{hr}$ via a nephrostomy tube from this kidney. He remained oliguric $\delta$ and an arteriovenous shunt was inserted in his left $₹$ leg but just before haemodialysis he had a cardiac 은 arrest and could not be resuscitated in spite of an $D$ indwelling pacemaker.

At post-mortem examination severe nephrocalcinosis, with widespread calculus formation and deposition of oxalate in the myocardium, testes, $\tilde{D}$ muscles and bone, was demonstrated. Histology of $\underset{\omega}{N}$ the kidney showed severely damaged kidneys with many obliterated glomeruli and pericapsular fibrosis. 0 There were masses of brilliantly birefractive crystals $\overparen{D}$ in radiating sheaves present in the tubules, interstitial $\stackrel{\odot}{\rightarrow}$ tissues and occasional glomeruli. Blood vessel walls 0 were thickened and some narrowed by intimal 
fibrosis. The picture was consistent with renal damage due to oxalosis.

\section{Discussion}

There is no known specific treatment for systemic oxalosis. The great majority of cases become manifest in the first decade, and death from renal failure frequently occurs in childhood or adolescence. Cases have been reported in adults, like the patient, and they seem to differ from the infantile primary hyperoxaluria in being less severe, rarely having a family history of the disease, and frequently with no preceding history of renal disease (Cochran et al., 1968; Ludwig, 1963; Zollinger and Langiader, 1960).

As in this patient, previous authors, on ECG examination, have noted cardiac arrhythmia due to deposition of calcium oxalate crystals in the bundle of His (Edwards, 1957; Enger, Serck-Hanseen and Rokkones, 1965; Stauffer, 1960). Crystal deposition in the left ventricle may also contribute to congestive cardiac failure in a normotensive patient.

Diagnosis is usually obtained by urine analysis and microscopic examination of tissue. Haemodialysis can remove oxalate from the circulation (Zarembski et al., 1966), but it is not a successful method of long-term treatment because of the widespread nature of the underlying disease. Renal transplantation has been unsuccessful because of rapid accumulation of calcium oxalate in the grafted kidney (Williams and Smith, 1968).

This case is of interest inasmuch as he presented at the age of 28 years with no significant past history in spite of widespread systemic involvement with oxalate deposition. This re-emphasises the fact that patients with chronic renal failure may remain asymptomatic in spite of severely impaired function.

\section{Acknowledgments}

We are grateful to Mr P. H. Smith, Consultant Urologist, for his help in the management of this patient and to $\mathrm{Dr}$ L. M. Swinburne, Consultant Pathologist, for the histological studies.

Support from the Yorkshire Kidney Research Fund is gratefully acknowledged.

\section{References}

Cochran, M., Hodgkinson, A., Zarembski, P.M. \& Anderson, C.K. (1968) Hyperoxaluria in adults. British Journal of Surgery, 55, 121.

DeAN, B.M., Griffin, W.J. \& Watts, R.W.E. (1966) Primary oxaluria - the demonstration of a metabolic abnormality in kidney tissue. Lancet, i, 406.

EDWARDS, D.L. (1957) Idiopathic familial oxalosis. Archives of Pathology, 64, 546.

Enger, E., Serck-Hanseen, A. \& Rokkones, T. (1965). Oxalosis - a case report. Acta medica scandinavica, 177, 409.

Hockaday, T.D.R., Clayton, J.E., Frederick, E.W. \& Smith, L.W. (1964) Primary hyperoxaluria. Medicine. Baltimore, 43, 315.

LuDWIG, G.D. (1963) Renal calculi associated with hypcroxaluria. Annals of the New York Academy of Sciences, $104,621$.

Stauffer, M. (1960) Oxalosis - report of a case, with a review of the literature and discussion of the pathogenesis. New England Journal of Medicine, 263, 386.

Williams, H.E. \& Smith, L.H. (1968) Disorders of oxalate metabolism. American Journal of Medicine, 45, 715.

Wyngaarden, J.B. \& Elder, T.D. (1966) Primary hyperoxaluria and oxalosis. In: The Metabolic Basis of Inherited Disease, 2nd edn, p. 189. McGraw Hill, New York.

Zarembski, P.M., Hodgkinson, A. \& Parsons, F.M. (1966) Elevation of the concentration of plasma oxalic acid in renal failure, Nature, London, 212, 511.

ZOLlinger, H.V. \& LANGIADER, F. (1960) Oxalose. Virchows Archiv für pathologische Anatomie und Physiologie und für klinische Medizin, 333, 368. 